\title{
ROMINCKA FOREST - A MALACOFAUNA REFUGE OF EUROPEAN SIGNIFICANGE
}

\author{
MAGDALENA MARZEC
}

\begin{abstract}
Museum of Natural History, University of Wrocław, Sienkiewicza 21, 50-335 Wrocław, Poland (e-mail: magdamarzec@poczta.onet.pl)
\end{abstract}

ABSTRACT: A total of 60 species of land mollusc: 55 snails and 5 slugs were recorded in Romincka Forest as a result of malacological research of 16 sites, combined with additional qualitative search. Due to snail species richness Romincka Forest is among the richest within low-lying forests in Poland and within the whole Middle-European Lowland. It is especially rich in species belonging to the family Clausiliidae. Eleven of the snail species recorded: Columella aspera Waldén, Vertigo ronnebyensis (Westerlund), Aegopinella minor (Stabile), Oxychilus alliarius (Miller), Cochlodina orthostoma (Menke), Macrogastra latestriata (A. Schmidt), M. tumida (Rossmässler), Clausilia dubia Draparnaud, C. pumila C. Pfeiffer, C. cruciata Studer and Helicigona lapicida (Linnaeus), are new records for this part of Poland, or required the verification of old records. Differences in snail species abundance were examined in three habitat types: subcontinental dry-ground forest was richer (46 snail species) than alder-ash marshy forest (40) and glades (22). Dry-ground forest sites are also more uniform in composition.

KEY WORDS: terrestrial gastropods, forest snail fauna, Romincka Forest, NE. Poland, species richness

\section{INTRODUCTION}

Although the land mollusc fauna of Poland is, in general, well-known (RIEDEL 1988, WIKTOR 2004), the details of the distribution of many species remain to be determined, and parts of the country have not been studied for many years (WIKTOR \& RIEDEL 2002). In particular, the northern parts of the country have received much less attention than the mountains in the south. There are, however, significant areas in the north retaining elements of natural habitats (PAWŁOWSKA \& POKRYSZKO 1998), and recent work has shown that there are some rich faunas in such places. Thus CAMERON \& POKRYSZKo (2004, 2006) found rich faunas in the Białowieża Forest in the east and in Kaszuby to the west, and concluded that where human influence was small even quite small patches of forest could hold most of the original fauna. Where such activities were greater however, faunas might lack many of the original forest species as at Lake Hańcza in the Suwałki Lakeland (POKRYSZKO \& CAMERON 2006).

Within that Lakeland, the Romincka Forest retains many natural features. An initial investigation at one site revealed the presence of Chilostoma faustinum (Rossmässler, 1835), a typically Carpathian species previously known only in the south (MARZEC 2005), accompanied by a rich forest fauna. This paper reports on a more detailed study of faunas within the forest, and relates them to features of habitat and geographical distribution.

\section{STUDY AREA}

Romincka Forest is a compact forest of c. $360 \mathrm{~km}^{2}$ situated on both sides of the Polish-Russian border north-west of Suwałki. It is a part of the East European Lowland and belongs to Lithuanian Lakeland macro- 
region (KONDRACKI 2000). In the geobotanical division of Poland Romincka Forest belongs to North Section - Augustowski-Suwalski land (MATUSZKIEWICZ 2007). This area is characterised by the most severe climate in the Polish lowlands, with the lowest average annual temperature $\left(6.2^{\circ} \mathrm{C}\right)$, the lowest average temperature in February $\left(-5.5^{\circ} \mathrm{C}\right)$, the smallest number of days in year with average temperature over $0^{\circ} \mathrm{C}$ (247 days), the shortest growing season: number of days in year with average temperature over $5^{\circ} \mathrm{C}(194$ days), the highest number of days in the year with maximum temperature under $0^{\circ} \mathrm{C}$ (66 days), the highest number of days in year with minimum temperature under $-10^{\circ} \mathrm{C}$ (36 days), the highest number of days in year with snow-cover (100 days) (MATUSZKIEWICZ 2007).

The topography has been shaped by glaciation during the Pleistocene, leaving an undulating surface between 150 and $300 \mathrm{~m}$ a.s.l., which gives rise to a great variety of soil types dependent both on underlying deposits and drainage. In the past, preservation for hunting (GAUTSCHI \& WINSMANN-STEINS 1992) as well as for timber influenced the composition of the forest, and there is a great variety of forest types. Typical dry-ground forest (Tilio-Carpinetum) is abundant on better drained land, and much swampy forest in badly drained areas. Most of the forest is affected by human activity, and managed conifer forests now dominate. Overall, tree composition in the Polish part is $40 \%$ spruce, $22 \%$ oak, $19 \%$ pine, $11 \%$ birch, $6 \%$ alder, with only $2 \%$ made up by other species such as linden. Average age of stands is 48 years.

Within the Polish part of the forest, 16 sites (locations shown in Fig. 1) were chosen for sampling to re- flect the major types of semi-natural forest remaining, and do not represent the majority of heavily managed stands. They fall into three categories:

Sites A1-A7: subcontinental dry-ground forest Tilio-Carpinetum. Stands are composed mainly of oak or linden. They are 90 to 135 years old at particular sites. Spruce and additionally ash, alder, maple, elm, hornbeam and birch are usually present, and natural regeneration is occurring. Undergrowth is rather poor. In comparison to the forest as a whole, these sites are characterised by the older trees and above average amount of dead wood, which remains until natural degradation occurs. Site A6 is in the Boczki nature reserve, and sites A5 and A7 both contain linden and oak seedling forests excluded from other economic use.

Sites B8-B14: alder-ash marshy forest Fraxino-Alnetum. All these sites are situated in river valleys. Stands are usually dominated by 60 years old alder (sites B8-10) or 80-120 years old alder (sites B11-14), but also contain spruce, linden, ash, and, less frequently, elm. Undergrowth is varied, with bird cherry, hazel, guelder rose, and saplings of canopy trees present at various sites. The field layer may be poor or rich and dense, with dominance of ground-elder (Aegopodium podagraria) and nettle (Urtica dioica). Site B11 is situated in the Czerwona Struga nature reserve. B8 and B10 sites were flooded recently.

Sites C15-C16: glades, sampled to detect the effect of clearance within a generally forested area. Treeless sites inside the forest, water-meadows in stream valley, partially drained and partially mowed. They are overgrown with sedge or grass and herbs. Site C16 is situated in the Struga Żytkiejmska nature reserve.

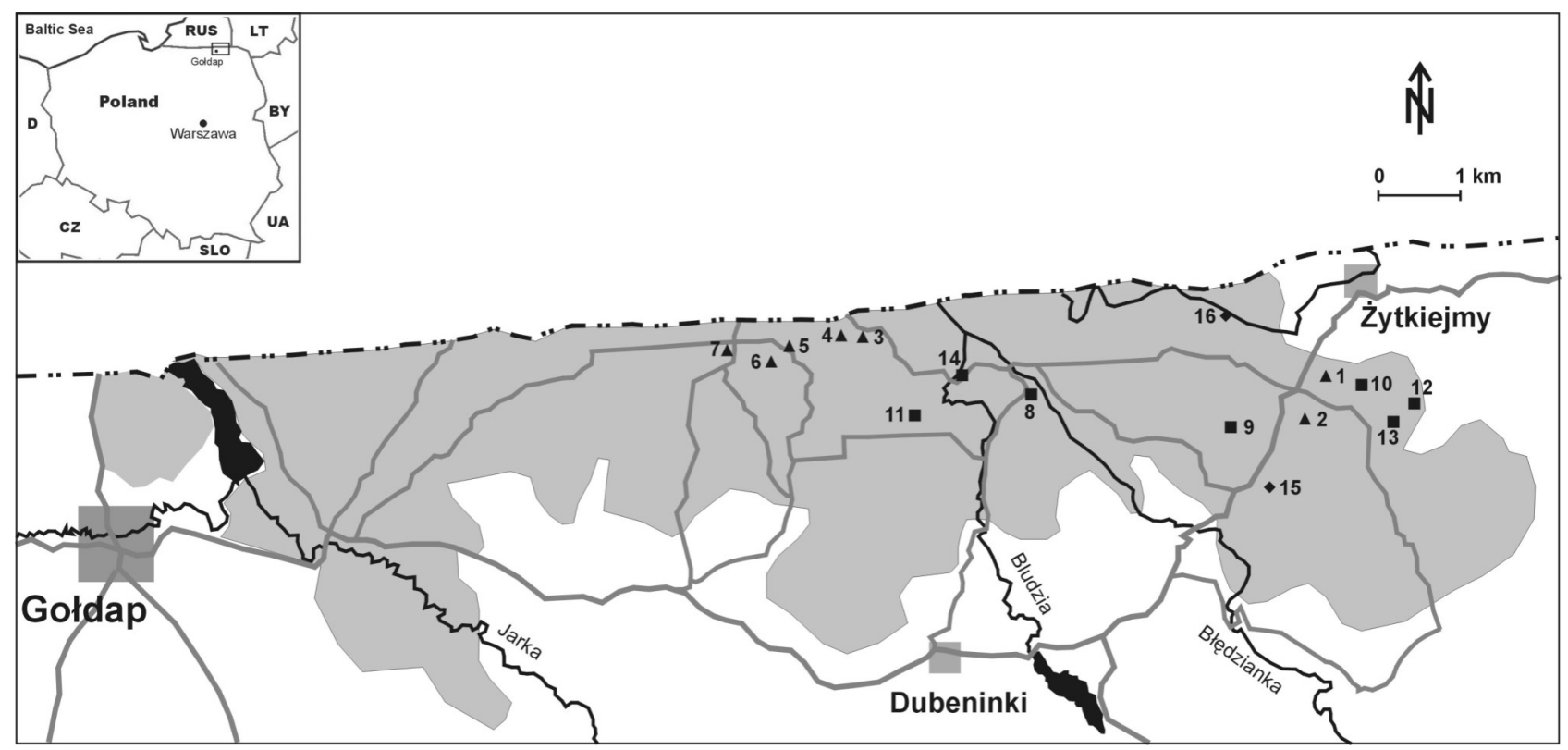

Fig. 1. Map of Romincka Forest location in Poland and location of sites in Romincka Forest area: 1-16 site numbers, triangle - dry-ground forest sites; square - marshy forest sites; diamond - glades, grey lines - roads; black lines - rivers; grey polygon - forest; grey squares - urban areas 


\section{METHODS}

Sampling was carried out in the summer and autumn periods between 2005 and 2007. More sites were investigated than eventually included here to ensure that those sampled would meet minimum requirements for sampling efficiency (CAMERON \& POKRYSZKO 2005). At each site an area of c. $400 \mathrm{~m}^{2}$ was searched by eye for at least two person-hours, and c. 101 of litter was collected from various microhabitats within the site and sieved in the field. Material passing through the sieve was bagged and sorted in the laboratory. Additional qualitative samples were made in some coniferous stands to check for additional species not living in the habitats selected for detailed study. At one site (A5) sampling was repeated in two seasons.

The completeness of inventories was checked using the Chao 1 Estimator (SOUTHWOOD \& HENDER-

\section{RESULTS}

\section{THE FAUNA OVERALL}

A total of 60 species of land mollusc were recorded during the study, of which five were slugs (Table 1). Among the snails, 52 species were recorded in the standard samples, and three further species were found only elsewhere; two, Vertigo ronnebyensis and Columella aspera, in the qualitative studies in coniferous woods, and the other, Helix pomatia, in brushwood along forest roads. The slugs, not adequately sampled by the methods used, are generally excluded from further analysis.

Twelve of the snail species recorded (asterisked in Table 1), including Chilostoma faustinum (MARZEC 2005), are new records for this part of Poland, or required the verification of old records. Six of these are clausiliids, doubling the known representation of this family in the area. Six species (in bold in Table 1) are listed as near threatened in the Polish Red List (WIKTOR \& RIEDEL 2002), and one of these, Helicigona lapicida, has legal protection.

\section{SPECIES RICHNESS AND FAUNAL ASSOCIATIONS WITH HABITAT}

The composition of the snail fauna at each of the 16 standard sites is shown in Table 2, and the summary statistics in Table 3, which also shows the Chao 1 estimates of species missed, based on the mean number of species represented by one and two individuals in each site by habitat. In general, the latter shows that site inventories are nearly complete, but at the site (A5) sampled on two occasions, an aggregate of 40 species was recorded from samples containing
SON 2000), regarded as one of the most reliable estimators of overlooked species (WALTHER \& MOORE 2005). Because error limits are wide when numbers of single and double specimens are small, mean values of these per site have been used in each habitat category (CAMERON et al. 2006). Similarity of faunas was assessed using the Nei index on presence and absence data (POKRYSZKO \& CAMERON 2005) and by Whittaker's index of Diversity (SOUTHWOOD \& HENDERSON 2000). Dominance in the faunas (ALEXANDROWICZ 1987) was not estimated as numbers do not reflect real densities, and relative numbers vary with season (MARZEC unpublished). Frequency of occurrence in the two forest types is used as an approximate indicator of habitat preference, but the number of sites is too small to sustain statistical analyses.

32 (summer) and 37 (autumn) species respectively (Appendix 1). Tilio-Carpinetum sites are richer than those of Fraxino-Alnetum, but with much overlap in values. The two glade sites are much poorer. Whittaker's index indicates that Tilio-Carpinetum sites are more uniform in composition than those in the Fraxino-Alnetum (see also below).

The complete set of site-by-site Nei similarities is shown in Appendix 2, and Table 4a shows the mean values within and between the three habitats. Tilio-Carpinetum sites are very similar to each other, but those from Fraxino-Alnetum are more heterogeneous; indeed, the mean similarity of these sites to those in Tilio-Carpinetum is marginally greater than among themselves. This difference is confirmed by the difference in the number of species occurring in all sites in each habitat, 16 out of 46 in Tilio-Carpinetum against only 5 out of 40 in the Fraxino-Alnetum. Inspection of Appendix 2 shows that B8, B9, and B10 are less similar both to each other and to other non-glade sites than B11-14. They are species-poor, and conspicuously low on clausiliids; one has none, the other two have only one species. Remaining forest sites have a minimum of three species, a median of seven and a maximum of 10. Excluding these sites (Table 4b), the remaining forest sites show great similarity; there is little distinction between the two types. These poor sites resemble those of the glades to a greater extent than the remaining forest sites. They and the glades appear to have subsets of the fauna present in the remainder, though not the same subset in each.

Many species are common to all three habitats studied (Table 5), but some are found only in one or two. While it is unsafe to regard records of species found in 
Table 1. Land snails present in Romincka Forest (sequence and nomenclature follow KERNEY et al., 1983). Asterisked species are new records for this part of Poland, in bold - species listed as near threatened in the Polish Red List (see text for more details)

Aciculidae

1. Acicula polita (Hartmann, 1840)

Ellobiidae

2. Carychium minimum O. F. Müller, 1774

3. Carychium tridentatum (Risso, 1826)

Succineidae

4. Succinea oblonga Draparnaud, 1801

5. Succinea putris (Linnaeus, 1758)

Cochlicopidae

6. Cochlicopa lubrica (O. F. Müller, 1774)

7. Cochlicopa lubricella (Porro, 1838)

8. Cochlicopa nitens (Gallenstein, 1848)

Vertiginidae

9. Columella edentula (Draparnaud, 1805)

10. Columella aspera* Waldén, 1966

11. Vertigo pusilla O. F. Müller, 1774

12. Vertigo antivertigo (Draparnaud, 1801)

13. Vertigo substriata (Jeffreys, 1833)

14. Vertigo pygmaea (Draparnaud, 1801)

15. Vertigo ronnebyensis* (Westerlund, 1871)

16. Vertigo alpestris Alder, 1838

Pupillidae

17. Pupilla muscorum (Linnaeus, 1758)

Valloniidae

18. Vallonia costata (O. F. Müller, 1774)

19. Vallonia pulchella (O. F. Müller, 1774)

20. Acanthinula aculeata (O. F. Müller, 1774)

Enidae

21. Ena obscura (O. F. Müller, 1774)

Endodontidae

22. Punctum pygmaeum (Draparnaud, 1801)

23. Discus ruderatus (Férussac, 1821)

24. Discus rotundatus (O. F. Müller, 1774)

Arionidae

25. Arion subfuscus (Draparnaud, 1805)

26. Arion circumscriptus Johnston, 1828

Vitrinidae

27. Vitrina pellucida (O. F. Müller, 1774)
Zonitidae

28. Vitrea crystallina (O. F. Müller, 1774)

29. Aegopinella pura (Alder, 1830)

30. Aegopinella minor* (Stabile, 1864)

31. Nesovitrea hammonis (Ström, 1765)

32. Nesovitrea petronella (L. Pfeiffer, 1853)

33. Oxychilus alliarius* (Miller, 1822)

34. Zonitoides nitidus (O. F. Müller, 1774)

Limacidae

35. Limax cinereoniger Wolf, 1803

36. Malacolimax tenellus O. F. Müller, 1774

37. Lehmannia marginata (O. F. Müller, 1774)

Euconulidae

38. Euconulus fulvus (O. F. Müller, 1774)

39. Euconulus alderi (Gray, 1840)

Clausiliidae

40. Cochlodina laminata (Montagu, 1803)

41. Cochlodina orthostoma* (Menke, 1830)

42. Ruthenica filograna (Rossmässler, 1836)

43. Macrogastra ventricosa (Draparnaud, 1801)

44. Macrogastra plicatula (Draparnaud, 1801)

45. Macrogastra latestriata* (A. Schmidt, 1857)

46. Macrogastra tumida* (Rossmässler, 1836)

47. Clausilia dubia* Draparnaud, 1805

48. Clausilia pumila* C. Pfeiffer, 1828

49. Clausilia cruciata* Studer, 1820

50. Laciniaria plicata (Draparnaud, 1801)

51. Bulgarica cana (Held, 1836)

Bradybaenidae

52. Bradybaena fruticum (O. F. Müller, 1774)

Helicidae

53. Perforatella bidentata (Gmelin, 1788)

54. Trichia hispida (Linnaeus, 1758)

55. Euomphalia strigella (Draparnaud, 1801)

56. Arianta arbustorum (Linnaeus, 1758)

57. Helicigona lapicida* (Linnaeus, 1758)

58. Chilostoma faustinum* (Rossmässler, 1835)

59. Cepaea hortensis (O. F. Müller, 1774)

60. Helix pomatia Linnaeus, 1758 


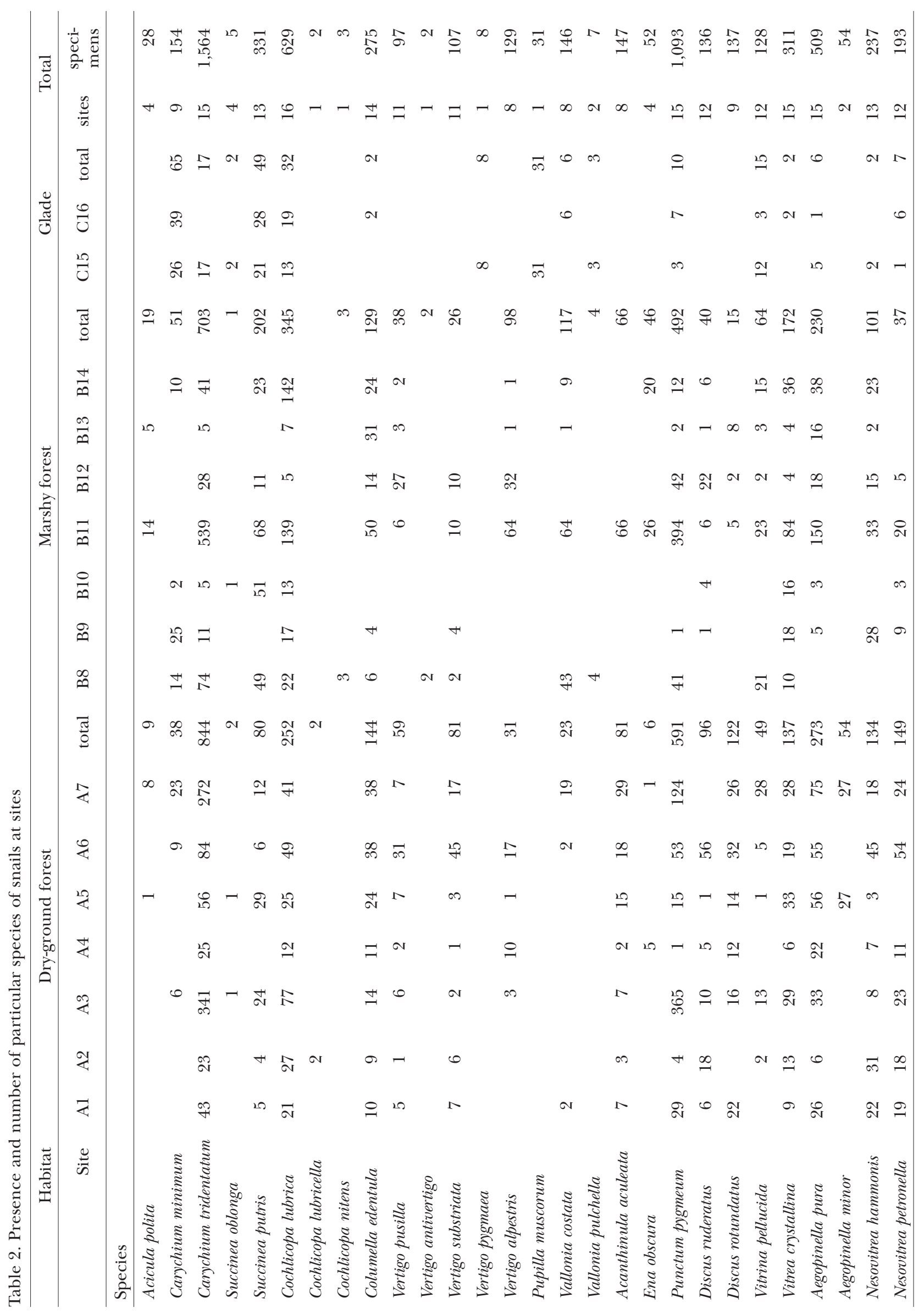




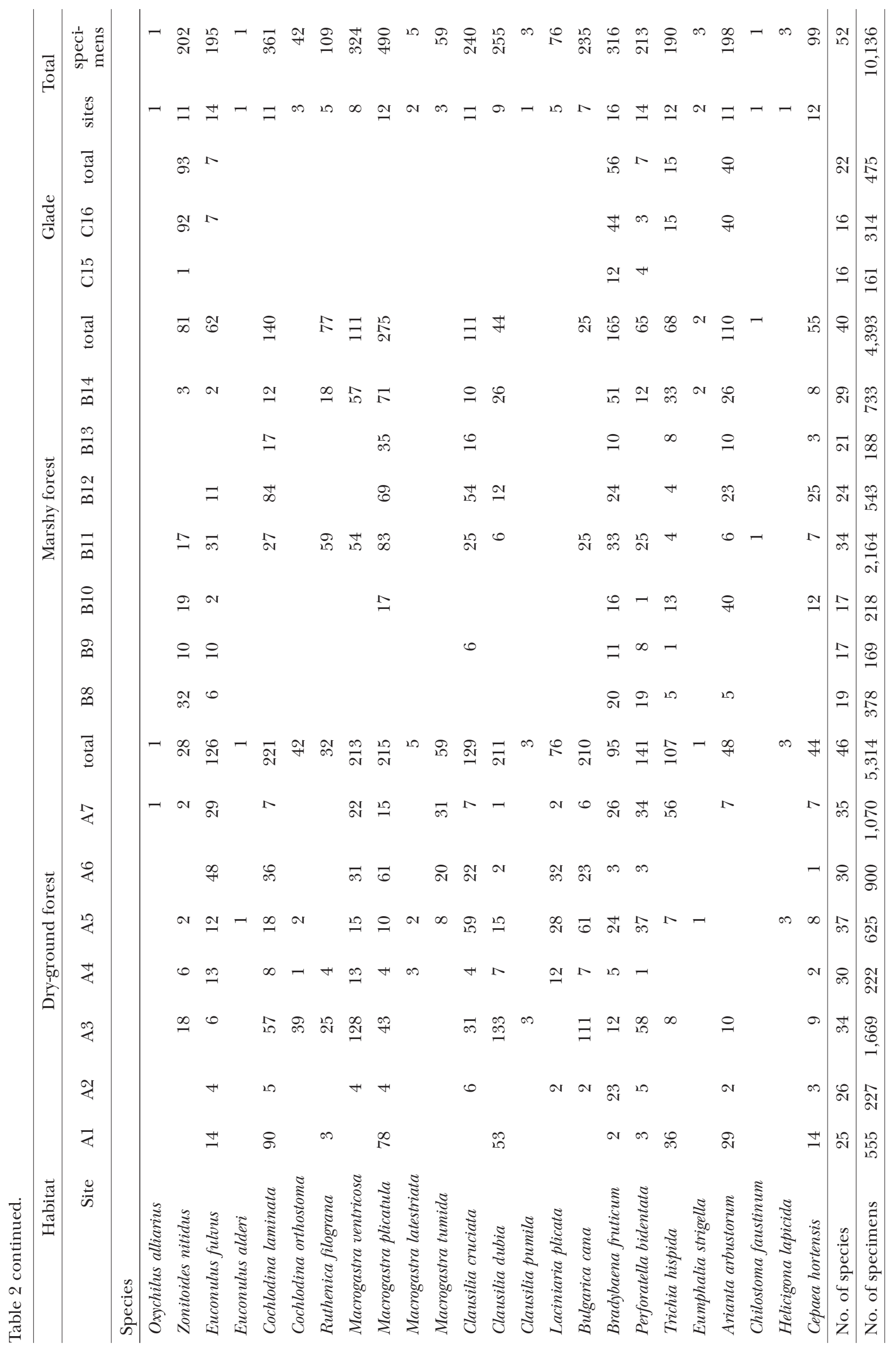


Table 3. Comparison of studied habitats - summary

\begin{tabular}{|c|c|c|c|c|}
\hline Habitat & Dry-ground forest & Marshy forest & Glade & Total \\
\hline No. of sites & 7 & 7 & 2 & 16 \\
\hline Total species & 46 & 40 & 22 & 52 \\
\hline Mean species/site & 31.0 & 23.0 & 16.0 & 25.6 \\
\hline Range & $25-37$ & $17-34$ & $16-16$ & $16-37$ \\
\hline No. of snail specimens & 5,268 & 4,393 & 475 & 10,136 \\
\hline Mean specimens/site & 752.6 & 627.6 & 237.5 & 633.5 \\
\hline Range & $222-1,669$ & $169-2,164$ & $161-314$ & $161-2,164$ \\
\hline Chao 1 estimate of missing species/site & 1.1 & 0.8 & 0.6 & \\
\hline Whittaker's index & 1.48 & 1.74 & $\mathrm{n} / \mathrm{a}$ & \\
\hline
\end{tabular}

Table 4. Mean values of the Nei index ( \pm Standard Error) in site-by-site comparisons within and among habitats: TC Tilio-Carpinetum, FA (B8-10, B11-14) - Fraxino-Alnetum (see text for more details)

a. main types of habitat

\begin{tabular}{cllll}
\multicolumn{2}{l}{ a. main types of habitat } \\
\hline $\mathrm{n}$ & & $\mathrm{TC}$ & FA & Glades \\
\hline 7 & TC & $0.803 \pm 0.01$ & $0.702 \pm 0.028$ & $0.534 \pm 0.022$ \\
7 & FA & & $0.679 \pm 0.022$ & $0.596 \pm 0.032$ \\
2 & Glades & & & $0.625 \mathrm{n} / \mathrm{a}$ \\
\hline
\end{tabular}

b. Fraxino-Alnetum sites divided into two subgroups

\begin{tabular}{rlllll}
\hline $\mathrm{n}$ & & TC & B8-10 & B11-14 & Glades \\
\hline 7 & TC & $0.803 \pm 0.01$ & $0.604 \pm 0.016$ & $0.775 \pm 0.012$ & $0.534 \pm 0.022$ \\
3 & B8-10 & & $0.662 \mathrm{n} / \mathrm{a}$ & $0.615 \pm 0.017$ & $0.674 \pm 0.037$ \\
4 & B11-14 & & & $0.816 \pm 0.014$ & $0.540 \pm 0.037$ \\
2 & Glades & & & $0.625 \mathrm{n} / \mathrm{a}$ \\
\hline
\end{tabular}

Table 5. Habitat preferences of species: bold - species present at more than one site, underlined - species present at all sites in given habitat, normal type - species present in single sites

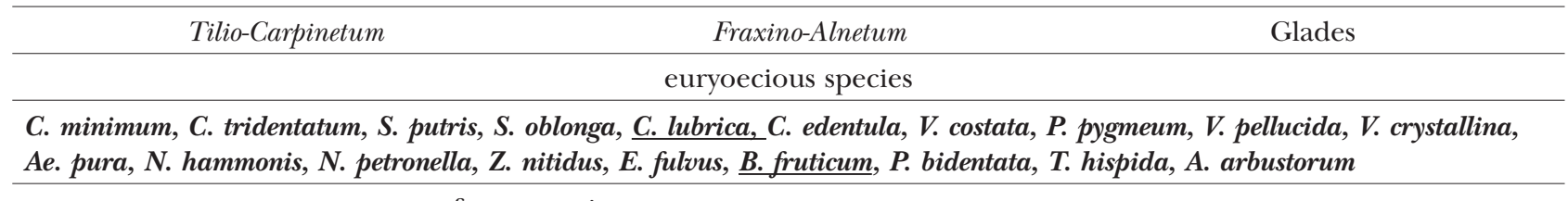

forest species

A. polita, V. pusilla, V. substriata, V. alpestris, A. aculeata, E. obscura, D. ruderatus,

D. rotundatus, C. laminata, $R$. filograna, $M$. ventricosa, M. plicatula, C. cruciata, C.

$\mathrm{X}$

dubia, B. cana, E. strigella, C. hortensis

unique/characteristic species

C. lubricella, A. minor, O. alliarius, E.

alderi, C. orthostoma, M. latestriata, M.

tumida, C. pumila, L. plicata, H. lapicida

C. nitens, V. antivertigo, Ch. faustinum V. pygmea, P. muscorum

one site only as indicating a habitat preference, it can be noticed that 10 species are confined to Tilio-Carpinetum, three to Fraxino-Alnetum, and two to glades (the latter, $P$. muscorum and $V$. pygmaea, being typical of open habitats). One species, $V$. pulchella, not shown in the Table, occurred only in glades and Fraxino-Alnetum. In general, as would be expected from the greater mean number of species per site, most species occur more frequently in Tilio-Carpinetum than in Fraxino-Alnetum, and this is most evident in the case of clausiliids (see above, and Table 2). It is, however, worth noting that apart from the two species ( $V$. antivertigo and C. nitens), each recorded in one Fraxino-Alnetum site, species normally associated with wet conditions are usually more-or-less equally or more frequent in the Tilio-Carpinetum sites (V. substriata, S. putris, Z. nitidus, S. oblonga, A. arbustorum). Apart from some clausiliids, the one striking difference between the forest types is seen in A. aculeata, which occurs in all 7 Tilio-Carpinetum sites, but in only one from Fraxino-Alnetum. 


\section{DISCUSSION}

\section{COMPLETENESS OF SITE INVENTORIES}

While the Chao estimates suggest that sampling was adequate, the case of one site (A5), where inventories were made at two different times of year, shows that no single check can be guaranteed to find all the species which occur at a site. The abundance of particular species and hence their detectability changes during the year (UMIŃSKI \& FOCHT 1979, SZYBIAK 2002, KORALEWSKA-BATURA et al. 2006, KORALEWSKA-BATURA \& BŁOSZYK 2007). In general, incomplete inventories will exaggerate the differences between sites (CHAO et al. 2005). The major general conclusion here is that all the undisturbed forest sites are very similar. Any sampling bias would tend to work against this conclusion; it can be regarded as robust. Similarly, while it is possible that there are further species, not yet detected, present in Romincka Forest, it seems likely that the range of sampling dates and seasons has given a reliable inventory of the forest fauna as a whole, at least for those forest types examined in detail.

\section{RICHNESS AND COMPOSITION OF SITE FAUNAS}

The means and ranges of site species richness are very similar to those reported from other European forests (POKRYSZKO \& CAMERON 2005). As in Białowieża, the Tilio-Carpinetum sites are on average richer than those from the Fraxino-Alnetum, though the latter are affected by the relative poverty of sites B8, B9 and $\mathrm{B} 10$. These results show that, as elsewhere, relatively undisturbed forests away from limestone can carry locally rich faunas that are revealed when the sampling regime is thorough.

Also as in Białowieża (CAMERON \& POKRYSZKO 2004), sites in Tilio-Carpinetum have very similar faunas, as revealed both by the Nei index and Whittaker's index of diversity; in both forests, the Fraxino-Alnetum (or sites in a similar vegetation type) are less so, with more differences among sites. Here, at least part of that heterogeneity is due to the rather disturbed nature of Sites B8-B10. The main difference between these and the remaining sites is the age of the trees, but the differences could also be influenced by periodic flooding of some fragments of the forests (B8 and B10). When this division among Fraxino-Alnetum sites is allowed for, the Nei analysis showed that old-growth sites (B11-B14) in this category were very similar both among themselves, and to the very uniform Tilio-Carpinetum sites. This division of riparian sites into two subgroups also shows that there are similarities between the group with young trees (and those subject to flooding) and the open sites (glades); disturbed sites share common and tolerant species, though as a group they are less uniform in their faunas than those in the old-growth forests.
In Białowieża, the distinction between Tilio-Carpinetum and Circaeo-Alnetum sites was rather clearer, though not absolute; the latter category did not include such disturbed sites. However, in poorer and more heavily managed forests (Melitto-Carpinetum) there were also low mean site richness and considerable heterogeneity. While the number of sites is small, it is evident that, within the range of forest communities studied here the nominal plant association of a site is of less importance than other factors, perhaps the degree and nature of disturbance most of all. Other studies also emphasise the role of factors other than forest type (KORALEWSKA-BATURA \& BŁOSZYK 2007, SUlikOWSKA-DROZD \& HORSÁK 2007). However, there are some differences between the forest types (for example the incidence of A. aculeata) that would repay further study.

\section{THE FOREST FAUNA AS A WHOLE}

The land mollusc fauna of Romincka Forest, with its 60 species of terrestrial gastropods, is among the richest within low-lying forests in Poland and within the whole Middle-European Lowland. In terms of snails (excluding slugs) Romincka Forest is as rich as Białowieża Forest ( 55 species), being bettered only by certain mountain forests, especially in the Pieniny range (POKRYSZKO \& CAMERON 2005 and the literature cited there).

Compared with other forests belonging to the same region (forests of North-East Europe, POKRYSZKO \& CAMERON 2005) Romincka Forest is especially rich in species of the family Clausiliidae. With regard to the number of clausiliid species (12), Romincka Forest is richer than the majority of low-lying forests in Middle and North-East Europe (PILÂTE 2003, POKRYSZKO \& CAMERON 2005, SZYBIAK \& LEŚNIEWSKA 2005). Only two species present in the East-European Lowland have not been observed in Romincka Forest in our times: Clausilia bidentata and Balea biplicata. Both of these species were found at the beginning of the 20th century by German researchers from the East Prussia area (RIEDEL 1988). Romincka Forest is situated within this historical area. C. bidentata is known in recent times in Białowieża (CAMERON \& POKRYSZKO 2004). The richness of clausiliids in the studied area is also reflected in the number of species at single sites. In this regard, Romincka Forest has the richest sites in the European Lowland - 10 species. In Białowieża Forest (equally abundant in clausiliid species) and in the rich Kaszubian forests there are a maximum of eight clausiliid species per site (CAMERON \& POKRYSZKO 2004, 2006). Richer clausiliid faunas do occur in the Carpathians (POKRYSZKO \& CAMERON 2005, SULIKOWSKA-DROZD 2005, SZYBIAK \& LEŚNIEWSKA 2005), which are abundant in species unique 
to that area (POKRYSZKO \& CAMERON 2005). In this area as many as 16 species have been observed among sets of 5-8 sites closer together than those considered here (POKRYSZKO \& CAMERON 2005), but the maximum at any one site is also 10; commonly, 8-9 species can be found at a single site (JUŘIČKOVÁ et al. 2005, SULIKOWSKA-DROZD 2005). Clausiliid faunas further west, in the Sudetes, are generally poorer at site level (POKRYSZKO \& CAMERON 2005).

Romincka Forest does not follow the pattern observed by POKRYSZKO \& CAMERON (2005) whereby the density of clausiliids in different forests in Europe is similar, a higher number of species being associated with a decrease in the number of individuals per species. Many sites in Romincka Forest are rich in terms of both number of clausiliid species and number of specimens. The highest number of specimens of clausiliids per single species (over 63) is observed at the site with one of the highest number of species (A3, with 9 clausiliid species).

The fauna of Vertiginidae is also rich, reflecting the very wet character of many sites, while that of Helicoidea is rather limited, reflecting the absence of limestone and the harsh climatic conditions. Even so, the presence of $H$. lapicida and C. faustinum is noteworthy.

In terms of species composition, Romincka Forest is very similar to Białowieża Forest, which lies $200 \mathrm{~km}$ to the south-east. The snail faunas have the same overall diversity (55 species), and 47 of these are held in common $(85 \%)$. Differences in the species composition of the two forests are shown in Table 6. Many of the species unique to one or the other have rather special habitats that may have been accidentally missed.

Among clausiliids, the areas differ by only one species - Clausilia cruciata is present in Romincka Forest only, while Clausilia bidentata occurs in Białowieża Forest only (CAMERON \& POKRYSZKO 2004). They both hold $M$. latestriata - a boreal mountain species, rare in lowlands - and M. tumida, a Carpathian species which is not otherwise present in the Polish Lowland and neighbouring Baltic countries (SKUJIENÉ 2002). The presence of Clausilia cruciata in Romincka Forest may be linked to the particularly severe climate in this area. The distribution of this species in the Polish Carpathian Mountains was linked with the distribution of sites with average annual temperature below $+6^{\circ} \mathrm{C}$ (SUlikOWSKA-DROZD 2005). The nearest known site of C. cruciata is in Augustowska Forest (POKRYSZKO \& CAMERON, unpublished), within the same severe climatic zone as Romincka Forest.

Both Romincka and Białowieża forests thus hold a mixture of boreal/montane and lowland species. SZYBIAK \& LEŚNIEWSKA (2005) observed 65 species of snails in total (excluding slugs) in Carpathian beech forest and in the beech forest of the West Poland lowlands. Romincka Forest is more similar to both lowland beech (32 species in common) and to Carpathian beech (30 species in common) than lowland and mountain beech forests are to each other (19 species in common).

Table 6. Comparison between Romincka and Białowieża Forests

\begin{tabular}{lcc}
\hline & Białowieża Forest & Romincka Forest \\
\hline Number of species present & (CAMERON \& POKRYSZKO 2004) & 60 \\
Number of snail species (slugs excluded) & 53 & 55 \\
No of Vertiginidae species: & 55 & 8 \\
No of Zonitidae species: & 8 & 7 \\
No of Clausiliidae species: & 12 & 12 \\
No of Helicidae species: & 9 & 8 \\
\hline Species in common & & \\
\hline Species present in one forest only & Clausilia bidentata & Oxychilus alliarius \\
\hline western species & Helicigona lapicida \\
& Isognomostoma isognomostoma & Euconulus alderi \\
mountain, carpathian or & Perforatella vicina & Chilostoma faustinum \\
boreal-mountain species & Vertigo moulinsiana & Clausilia cruciata \\
rare species & Vertigo angustior & Vertigo ronnebyensis \\
common species & Oxyloma elegans & Prianta arbustorum
\end{tabular}


As in Białowieża (CAMERON \& POKRYSzKo 2004), and in Kaszuby (CAMERON \& POKRYSZKO 2006), these rich northern faunas are dependent on stands of ancient and at least semi-natural forest. A direct comparison can be made with the faunas reported from secondary and disturbed forests around Lake Hańcza (Pokryszko \& CAMERON 2006), which is only $20 \mathrm{~km}$ distant, with similar climate and range of soils. In 10 sites sampled in the same way as in this study only 29 species of snails were found, and no clausiliids at all. Similarly, most forest fragments in Wielkopolska are depauperate, usually with no more than three clausiliid species (CAMERON \& POKRYSZKO 2006, KORALEWSKA-BATURA et al. 2006). The occurrence of typical forest species also depends on forest plot size (KAPPES et al. 2009). The large and relatively dense forest complex represented by Romincka Forest is a natural refuge for typical forest species. Many rare species are present, to which woodcutting is the major threat (PAWŁOWska \& Pokryszko 1998). These include $V$. alpestris, E. obscura, R. filograna, M. ventricosa, as well as species which appear on the Polish Red List: $N$. petronella, M. latestriata, M. tumida, C. cruciata (WIKTOR \& RIEDEL 2002).

An important factor contributing to the biodiversity of Romincka Forest is the hilly, postglacial landform. This provides a diversity of sites potentially attractive to molluscs, especially in watercourse areas linked to flows or swampy depressions. Landform features may also exert an indirect influence. The presence of hills, steep slopes and deep ravines results in less economic exploitation of such territory; inaccessible regions are often excluded from extensive forest exploitation. As HYLANDER et al. (2004) and SHIKOV (1984) demonstrated, even a small patch of forest with a suitable environment or old-growth trees may ensure the survival of some species of snails in a managed forest. This is true in Romincka Forest, where four of six sites characterised by a species count of at least 30 are not subject to human exploitation (they are located within nature reserves or seminal forest stand areas). Legislative measures to protect regions of biological importance are indispensable.

\section{ACKNOWLEDGEMENT}

I am very much obliged to Mr. ANDRZEJ WYŁUCKI, forest inspector, Forest Inspectorate Gołdap, for suspending forest works and excluding from exploitation the most abundant snail site in Romincka Forest which is also the only site with Helicigona lapicida. This paper was written thanks to invaluable help and involvement of Prof. BEATA M. POKRYSZKo and Prof. Robert A. D. CAMERON. I would also like to thank Dr. TOMASZ K. MALTZ and Ms. KATARZYNA SIWAK for their help with the field and laboratory work.

\section{REFERENCES}

AleXANDrowicz S. W. 1987. Analiza malakologiczna w badaniach osadów czwartorzędowych. Wyd. AGH, Geologia 12: 1-240.

CAmeron R. A. D., Pokryszko B. M. 2004. Land mollusc faunas of Białowieża forest (Poland), and the character and survival of forest faunas in the North European Plain. J. Moll. Stud. 70: 149-164.

Cameron R. A. D., Pokryszko B. M. 2005. Estimating the species richness and composition of land mollusc communities: Problems, consequences and practical advice. J. Conch. 38: 529-547.

CAmeron R. A. D., Pokryszko B. M. 2006. Forest snail faunas in the Kaszuby Uplands (Pomerania): a rich northern refuge. Folia Malacol. 14: 75-82.

CAmeron R. A. D., Pokryszko B. M., LONG D. C. 2006. Snail faunas in southern English calcareous woodlands: rich and uniform, but geographically differentiated. J. Conch. 39: 13-40.

Chao A., Chazdon R. L., Colwell R. K., Shen T.J. 2005. A new statistical approach for assessing similarity of species composition with incidence and abundance data. Ecol. Lett. 8: 148-159.

GAUTSCHi A., WinsmanN-STEInS B. 1992. Rominten Gestern und Heute. Nimrod, Bothel.

HylANDER K., NilsSON C., GÖTHNER T. 2004. Effects of buffer-strip retention and clearcutting on land snails in boreal riparian forests. Conserv. Biol. 18: 1052-1062.

JUŘičKOVÁ L., BERAN L., DVOŘAK L., HLAVÁC̆ J. Č., HORSÁK M., Hrabáková M., Maltz T. K., POKRYSZKo B. M. 2005. Mollusc fauna of the Rychlebské Hory (Chech Republic). Folia Malacol. 13: 9-23.

KAPPES H., JORDAENS K., HENDRICKX F., MAELFAIT J. P., LENS L., BACKELJAU T. 2009. Response of snails and slugs to fragmentation of lowland forests in NW Germany. Landscape Ecol. 24: 685-697.

Kerney M. P., CAmeron R. A. D., Jungbluth J. H. 1983. Die Landschnecken Nord- und Mitteleuropas. Paul Parey, Hamburg und Berlin.

KONDRACKI J. 2000. Geografia regionalna Polski. PWN, Warszawa.

KORALEWSKA-BATURA E., BŁOSZYK J. 2007. Stability of malacocoenoses in an ash-elm forest based on two-year observations. Folia Malacol. 15: 175-180.

Koralewska-BAtura E., BŁoszyK J., NAPIERAŁA A. 2006. Malacocoenoses of fragmented forests of Wielkopolska. Folia Malacol. 14: 1-9.

MARZEC M. 2005. A new locality of Chilostoma faustinum (Rossmässler, 1835) in the Romincka Forest (NE Poland). Folia Malacol. 13: 95-96. 
MATUSZKIEWICZ J. M. 2007. Zespoły leśne Polski. PWN, Warszawa.

PAWŁOWSKA E., POKRYSZKo B. M. 1998. Why are terrestrial gastropods of Poland threatened? Folia Malacol. 6: 63-71.

PILÂTE D. 2003. Fauna of terrestrial molluscs in the forests of Gauja National Park. Acta Biol. Univ. Daugavp. 3: 15-20.

Pokryszko B. M., CAMERon R. A. D. 2005. Geographical variation in the composition and richness of forest snail faunas in northern Europe. Rec. West. Austr. Mus., Suppl. 68: 115-132.

Pokryszko B. M., CAMERon R. A. D. 2006. Land snail communities at Lake Hańcza (NE. Poland). Folia Malacol. 14: 63-69.

RIEDEL A. 1988. Ślimaki lądowe Gastropoda terrestria. Kata$\log$ Fauny Polski 36. PWN, Warszawa.

SHIKOV E. V. 1984. Effects of land use changes on the land mollusc fauna in central portion of the Russian plain. In: SOlEM A., VAN BRUGGEN A. C. (eds.) World-wide snails. Biogeographical studies on non-marine Mollusca. E. J. Brill/W. Backhuys, Leiden, pp. 237-248.

SKUJIENÉ G. 2002. An overview of the data on the terrestrial molluscs in Lithuania. Folia Malacol. 10: 1-7.

Southwood T. R. E., Henderson P. A. 2000. Ecological methods. Blackwell, Oxford.

SulikOWSKA-DROZD A. 2005. Distribution and habitat preferences of clausiliids (Gastropoda: Pulmonata:
Clausiliidae) in the eastern part of the Polish Carpathians. Folia Malacol. 13: 49-94.

SUlikowSKA-DrozD A., Horsák M. 2007. Woodland mollusc communities along environmental gradients in the East Carpathians. Biologia, Bratislava 62: 201-209.

SZYBIAK K. 2002. Malacocenoses of the nature reserve Buki nad Jeziorem Lutomskim. Folia Malacol. 10: 25-32.

SZYBIAK K., LEŚNIEWSKA M. 2005. Malacocenoses of five beech forests in Poland. Folia Malacol. 13: 181-188.

UMIŃSKI T., FOCHT U. 1979. Population dynamics of some land gastropods in a forest habitat in Poland. Malacologia 18: 181-184.

WALTher B. A., MOORE J. L. 2005. The concepts of bias, precision and accuracy, and their use in testing the performance of species richness estimatiors, with a literature review of estimator performance. Ecography 28: 815-829.

WikTOR A. 2004. Ślimaki lądowe Polski. Mantis, Olsztyn.

WIKTOR A., RIEDEL A. 2002. Ślimaki lądowe Gastropoda Terrestria. In: GŁOWACIŃSKI Z. (ed.) Red list of threatened animals in Poland, Polish Academy of Sciences, Institute of Nature Conservation, Kraków, pp. 27-33.

Received: May 15th, 2010

Accepted: June 5th, 2010

Appendix 1. Number of snail species and specimens at site A5 in summer and in autumn

\begin{tabular}{lcc}
\hline \multicolumn{1}{c}{ Date } & IX 2006 & VII 2007 \\
\hline Species & $\mathrm{n}$ & $\mathrm{n}$ \\
\hline Acicula polita & 1 & 2 \\
Carychium tridentatum & 56 & 151 \\
Succinea oblonga & 1 & - \\
Succinea putris & 29 & 5 \\
Cochlicopa lubrica & 25 & 6 \\
Columella edentula & 24 & 14 \\
Vertigo pusilla & 7 & 9 \\
Vertigo substriata & 3 & 15 \\
Vertigo alpestris & 1 & 1 \\
Acanthinula aculeata & 15 & 45 \\
Ena obscura & - & 3 \\
Punctum pygmeum & 15 & 159 \\
Discus ruderatus & 1 & - \\
Discus rotundatus & 14 & 8 \\
Vitrina pellucida & 1 & - \\
Vitrea crystallina & 33 & 8 \\
Aegopinella pura & 56 & 42 \\
Aegopinella minor & 27 & 9 \\
Nesovitrea hammonis & 3 & 1 \\
Nesovitrea petronella & - & 2 \\
Zonitoides nitidus & 2 & - \\
Euconulus fulvus & & 8 \\
\hline & & \\
\hline
\end{tabular}

\begin{tabular}{lcc}
\hline \multicolumn{1}{c}{ Date } & IX 2006 & VII 2007 \\
\hline Species & $\mathrm{n}$ & $\mathrm{n}$ \\
\hline Euconulus alderi & 1 & - \\
Cochlodina laminata & 18 & 14 \\
Cochlodina orthostoma & 2 & - \\
Macrogastra ventricosa & 15 & 13 \\
Macrogastra plicatula & 10 & 4 \\
Macrogastra latestriata & 2 & 4 \\
Macrogastra tumida & 8 & 4 \\
Clausilia cruciata & 59 & 23 \\
Clausilia dubia & 15 & - \\
Laciniaria plicata & 28 & 35 \\
Bulgarica cana & 61 & 20 \\
Bradybaena fruticum & 24 & 4 \\
Perforatella bidentata & 37 & 3 \\
Trichia hispida & 7 & 3 \\
Eumphalia strigella & 1 & - \\
Arianta arbustorum & - & 5 \\
Helicigona lapicida & 3 & 2 \\
Cepaea hortensis & 8 & 3 \\
\hline No. of species & 37 & 0.7 \\
\hline No. of specimens & 8.2 & \\
\hline Chao 1 Index & & 32 \\
\hline & & \\
\hline
\end{tabular}


Appendix 2. Similarity of sites expressed by Nei Index

\begin{tabular}{|c|c|c|c|c|c|c|c|c|c|c|c|c|c|c|c|}
\hline & A2 & A3 & A4 & A5 & A6 & A7 & B8 & B9 & B10 & B11 & B12 & B13 & B14 & C15 & C16 \\
\hline $\mathrm{A} 1$ & 0.784 & 0.823 & 0.767 & 0.690 & 0.803 & 0.778 & 0.596 & 0.679 & 0.679 & 0.857 & 0.857 & 0.742 & 0.780 & 0.450 & 0.650 \\
\hline A2 & & 0.807 & 0.788 & 0.742 & 0.859 & 0.796 & 0.540 & 0.666 & 0.618 & 0.807 & 0.801 & 0.685 & 0.728 & 0.490 & 0.588 \\
\hline A3 & & & 0.845 & 0.818 & 0.845 & 0.812 & 0.590 & 0.707 & 0.707 & 0.882 & 0.840 & 0.711 & 0.828 & 0.557 & 0.643 \\
\hline $\mathrm{A} 4$ & & & & 0.810 & 0.833 & 0.772 & 0.419 & 0.664 & 0.531 & 0.845 & 0.745 & 0.637 & 0.746 & 0.411 & 0.456 \\
\hline A5 & & & & & 0.810 & 0.806 & 0.490 & 0.598 & 0.558 & 0.789 & 0.738 & 0.682 & 0.733 & 0.452 & 0.493 \\
\hline A6 & & & & & & 0.864 & 0.545 & 0.664 & 0.576 & 0.845 & 0.820 & 0.717 & 0.780 & 0.502 & 0.593 \\
\hline A7 & & & & & & & 0.620 & 0.615 & 0.615 & 0.870 & 0.759 & 0.701 & 0.785 & 0.507 & 0.676 \\
\hline B8 & & & & & & & & 0.668 & 0.612 & 0.590 & 0.562 & 0.501 & 0.639 & 0.574 & 0.803 \\
\hline B9 & & & & & & & & & 0.706 & 0.666 & 0.693 & 0.582 & 0.676 & 0.606 & 0.728 \\
\hline B10 & & & & & & & & & & 0.624 & 0.644 & 0.529 & 0.676 & 0.606 & 0.728 \\
\hline B11 & & & & & & & & & & & 0.840 & 0.786 & 0.860 & 0.472 & 0.643 \\
\hline B12 & & & & & & & & & & & & 0.846 & 0.796 & 0.459 & 0.612 \\
\hline B13 & & & & & & & & & & & & & 0.770 & 0.382 & 0.546 \\
\hline B14 & & & & & & & & & & & & & & 0.511 & 0.696 \\
\hline C15 & & & & & & & & & & & & & & & 0.625 \\
\hline
\end{tabular}

